\title{
Human exposure to Salmonella spp from dog food containing raw meat - systematic review
}

\section{Exposição de humanos à Salmonella spp a partir de alimentos para cães contendo carne crua - revisão sistemática}

\author{
Jéssica Santana dos REIS'; Daianne Carneiro de Oliveira SANTOS ${ }^{1}$; Luciene Barbosa GOMIDE ${ }^{1}$; \\ Rosana Claudio Silva OGOSHI²; Luciano José PEREIRA ${ }^{1}$; Márcio Gilberto ZANGERONIMO ${ }^{1}$ \\ ${ }^{1}$ Universidade Federal de Lavras, Departamento de Medicina Veterinária, Lavras - MG, Brazil \\ ${ }^{2}$ Universidade do Alto Vale do Rio Peixe, Caçador - SC, Brazil
}

\begin{abstract}
Feeding dogs raw meat diets is an increasingly popular trend, and when contaminated with Salmonella they may present a risk to the health of both animals and humans. The present investigation is a systematic review of literature to assess the frequency of raw meat diets for dogs contaminated with Salmonella and whether dogs consuming these diets can eliminate it in their faeces. A search was made using two databases: "Web of Knowledge" and "PubMed" in January 2015. Only studies related to raw food diets and consumption by dogs were included. Thirteen articles were selected after refining the search. In 11 studies microbiological analysis was conducted for Salmonella in diets containing raw meat, so that in four of these studies Salmonella in the faeces was also analysed. In the analysis of 679 raw meat diets 141 diets $(20.76 \%)$ were contaminated with Salmonella, in which the serotype most commonly found was S. Typhimurium (24.60\%). Of the studies that reported the number of dogs that eliminated Salmonella in faeces after consumption of diets containing raw meat, 141 faecal samples were analysed, of which $73(51.77 \%)$ were contaminated with Salmonella and the serotype most commonly found was S. Newport (72.60\%). The available data suggest that the owners who feed their animals with diets containing contaminated raw meat, either commercial or homemade, are exposed to risk of Salmonella contamination, either by the manipulation of food or by handling the dog's stool.
\end{abstract}

Keywords: Food safety. Public health. Raw diet. Pet. Salmonella. Zoonosis.

\section{Resumo}

O emprego de dietas para cães contendo carne crua tem sido uma prática popular frequente. Estas, quando contaminadas por Salmonella, podem oferecer risco para a saúde dos animais e dos seres humanos. Este trabalho é uma revisão sistemática da literatura efetuada para avaliar a frequência de dietas para cães que continham carne crua contaminada por Salmonella, e se os cães que as consumiam eliminariam a bactéria em suas fezes. A pesquisa foi realizada em duas bases de dados, Web of Knowledge e PubMed, durante janeiro de 2015. Participaram da pesquisa trabalhos sobre dietas para cães contendo alimentos crus e seu consumo; treze artigos foram selecionados. Em 11 trabalhos foram conduzidas análises microbiológicas para Salmonella nas dietas contendo carne crua, sendo que em quatro desses estudos também foi analisada a presença da bactéria nas fezes dos animais. Em 679 dietas contendo carne crua, 141 delas (20,76\%) estavam contaminadas, sendo o sorotipo mais encontrado foi Salmonnela Typhimurium (24,60\% do total). Dos estudos que relataram a eliminação da bactéria após o consumo de dietas contendo carne crua, um total de 141 amostras fecais foram analisadas, das quais $73(51,77 \%)$ estavam contaminadas, e o sorotipo mais encontrado foi Salmonella Newport (72,60\% do total). Os resultados obtidos permitem afirmar que os proprietários dos cães alimentados por dietas (caseiras ou comerciais) a base de carne crua contaminada estão expostos ao risco de infecção por Salmonella tanto pela manipulação de alimentos como pelas fezes dos animais.

Palavras-chave: Segurança alimentar. Saúde pública. Dieta crua. Animal de companhia. Salmonella. Zoonoses. 
Correspondence to:

Márcio Gilberto Zangeronimo

Universidade Federal de Lavras, Departamento de Medicina

Veterinária

Av. Doutor Sylvio Menicucci, 1001

CEP 37200-000, Lavras, MG, Brazil

e-mail: zangeronimo@dmv.ufla.br

Received: 01/04/2017

Approved: 11/10/2017

\section{Introduction}

In recent years a growing number of dog owners have replaced the supply of conventional dry diets for their animals with "natural" food, either commercial or homemade, in which there is an increasing trend of containing raw meat. Raw meat-based diets are those that include uncooked ingredients derived from meat of domesticated or wild animal species, which are offered to dogs or cats living in home environments. These ingredients may be skeletal muscles, internal organs, and bones from mammals, fish, or poultry, as well as unpasteurized milk and uncooked eggs (FREEMAN et al., 2013).

The three most common types of homemade raw food diets are Bone and Raw Food Diet (BARF), Ultimate Diet ${ }^{\circledR}$, and Volhard Diet ${ }^{\circledR}$ (FREEMAN; MICHEL, 2001). Frozen raw food diets can also be found in some pet shops, veterinary clinics, grocery stores, pet foods' stores, and on the internet for home delivery (MEHLENBACHER et al., 2012), containing as main ingredients raw meat and vegetables, grains, and fruits (FINLEY et al., 2008a).

Feeding pets with these diets is a controversial issue among veterinarians, animal scientists, and owners with regard to the nutritional benefits and the risk that they pose to the health of both animals and humans (FREEMAN; MICHEL, 2001), especially when analysing issues of food safety and public health. Thus, there is a growing concern about the spread of faecal pathogens in the environment, especially Salmonella, following the growing practice of feeding pets raw meats (FINLEY et al., 2007).

In some cases uninspected products may come from diseased, debilitated, dying or dead animals (meat 4-D). This type of meat may contain pathogens, including Salmonella, Campylobacter jejuni, and Escherichia coli (CHENGAPPA et al., 1993). The situation is even worse when these products are not properly processed (e. g. by heating) before consumption (FINLEY et al., 2007). In Brazil animal products coming from slaughterhouses are inspected by the Municipal, State or Federal Inspection Services. Moreover, consumers normally buy meat in establishments supervised by the Official Health Surveillance. However, according to ABIEC (2014), it is estimated that the informal meat slaughter market in this country corresponds to $30 \%$, which compromises the safety of these products.

Dogs are usually subclinical carriers of Salmonella (FINLEY et al., 2007). Thus, the major concern regarding the use of diets based on raw meats is the risk of Salmonella contamination in food handlers, faeces, and feeders of animals (WEESE et al., 2005), especially in relation to immunocompromised individuals, most of all children, pregnant women, and the elderly (LENZ et al., 2009). On the other hand, no comprehensive or quantitative risk profile is available for pet foods, consequently limiting the ability to establish safety standards and assess the effectiveness of current and proposed Salmonella control measures (LAMBERTINI et al., 2016).

Thus, the purpose of this study was to conduct a systematic review to assess: (1) the frequency of raw meat diets for dogs contaminated with Salmonella, and (2) whether the dogs consuming diets contaminated with pathogens can eliminate them in their faeces, presenting the potential risk of human contamination.

\section{Materials and Methods}

\section{Identification and selection of studies}

This research was conducted in January of 2015 with data collected from PubMed (http://www.ncbi.nlm.nih.gov/ pubmed) and Web of Knowledge (https://goo.gl/mEa7G5), using the combination of the following keywords: 'raw food diets' or 'raw meat' and 'dogs', and either 'zoonoses', 'public health' or 'Salmonella'. Initially, searches were made using the combination of three keywords, but some searches were performed with only two keywords.

Only research articles that evaluated raw food diets consumed by dogs were selected. Research studies in other species, literature reviews, and other types of studies were excluded. No restriction was made regarding date or language.

\section{Eligibility criteria}

Literature research was carried out separately by three different researchers. The studies considered relevant were read in full by all authors separately. In case of disagreement the decision of which articles to be used in the study was made by reviewing the inclusion criteria and coming to 
a consensus. After the selection of relevant articles, the criteria for qualitative assessment of the methodology were determined.

\section{Assessment of enrolment criteria}

After the selection of articles qualitative analysis was performed so that scientific criteria were scored (Table 1). However, not all parameters used were qualified, with only those most relevant to the subsequent discussion being used. Based on another systematic review (PEREIRA et al., 2011) some parameters were classified as appropriate (score 3), appropriate but incomplete (score 2), and unsatisfactory or unclear (score 1). Other parameters were only classified as appropriate (score 2) or unsatisfactory/ unclear (score 1). The classification criteria were:

I) Types of samples analysed microbiologically: studies that performed microbiological analysis for Salmonella in raw meat diets and faeces of dogs that consumed them received score 3 ; studies in which the analysis was only performed in the diet received score 2; and studies in which the analysis was only performed in the faeces of the dogs received score 1.

II) Relationship between the serotype of Salmonella present in the feed and the type of raw meat and/or serotype of Salmonella excreted in the faeces: studies which showed the relationship between the type of raw meat and the Salmonella serotypes found in the diet and excreted in faeces received score 3; studies which described the relationship between type of raw meat and the Salmonella serotypes present in the food, or the relationship between Salmonella serotypes in food and those excreted in faeces received score 2; and studies which only described Salmonella serotypes present in food or faeces or were not clear on any of this information received score 1.

III) Source of acquisition of diet: studies which evaluated commercial and homemade diets received score 3 , studies evaluating commercial or homemade diets received score 2 ; and studies that did not evaluate the diet or were not clear on such information received score 1 .

IV) Time until elimination of the pathogen in the environment: studies that evaluated the time until elimination of the pathogen in the environment by dogs after consuming the contaminated diet received score 2, while those that did not perform the evaluation or were not clear on that information received score 1.

V) Methods for microbiological evaluation: studies conducted by conventional microbiological culture and/or using more accurate methods of analysis (like DNA-based diagnostics or Enzyme Linked Fluorescent) received score 2 , while studies performed only by microbiological culture received score 1.

VI) Description of sampling months: studies showing the relationship between the collection period and the prevalence of Salmonella in food and/or faeces received score 3; studies that reported only the period of sampling without relating it to the prevalence received score 2; and studies that did not report the period of sample collection or were not clear on such information received score 1 .

According to the criteria, the maximum score was 16 points.

Table 1 - Scores (from highest to lowest total) of articles selected according to the criteria for qualitative assessment

\begin{tabular}{cccccccc}
\hline Author & I & II & III & IV & V & VI & Total \\
\hline Lenz et al. (2009) & 3 & 2 & 2 & 1 & 1 & 2 & 11 \\
Chengappa et al. (1993) & 2 & 1 & 1 & 1 & 2 & 3 & 10 \\
Joffe and Schlesinger (2002) & 3 & 3 & 1 & 1 & 1 & 1 & 10 \\
Morley et al. (2006) & 3 & 3 & 1 & 1 & 1 & 1 & 10 \\
Finley et al. (2007) & 3 & 2 & 1 & 2 & 1 & 1 & 10 \\
Strohmeyer et al. (2006) & 2 & 1 & 1 & 1 & 1 & 3 & 9 \\
Leonard et al. (2011) & 1 & 1 & 2 & 2 & 1 & 2 & 9 \\
Nemser et al. (2014) & 2 & 1 & 1 & 1 & 2 & 2 & 9 \\
Mehlenbarcher et al. (2012) & 2 & 2 & 1 & 1 & 1 & 1 & 8 \\
Freeman e Michel (2001) & 2 & 1 & 1 & 1 & 1 & 1 & 7 \\
Weese, Rousseau e Arroyo (2005) & 2 & 1 & 1 & 1 & 1 & 1 & 7 \\
Lefebvre et al. (2008) & 1 & 1 & 2 & 1 & 1 & 1 & 7 \\
\hline
\end{tabular}

I: analysis for the identification of Salmonella in the diet and in the faeces of dogs (score 3), analysis only of the diet (score 2), analysis only of the faeces (score 1), II: demonstrated the relationship between type of raw meat, serotype Salmonella in the diet, and serotype of Salmonella in the faeces (score 3); demonstrated the relationship between type of raw meat and serotype of Salmonella in the food or the relationship between the serotype of Salmonella in food and the one excreted in the faeces (score 2); demonstrated the serotype of Salmonella in food or faeces or some of this information was not clear (score 1), III: evaluation in homemade and commercial diets (score 2), assessment in homemade or commercial diet (score 1); IV: evaluation of the time of elimination of Salmonella in faeces after consumption of a contaminated diet (score 2); no evaluation or results were not clear (score 1); V: conducting microbiological analysis by conventional culture and/or using more accurate methods of analysis (such as through DNA-based diagnostic or Enzyme Linked Fluorescent) (score 2); performance of microbiological analysis only with culture medium (score 1); VI: relationship between month of collection and prevalence of Salmonella (score 3); reported the period of sample collection (score 2); results were not reported or unclear (score 1 )

\section{Results}

The PubMed research resulted in 98 articles, while the research on the Web of Knowledge resulted in 40 articles. Of the 138 articles found, only 13 were selected for the present study (Figure 1). 


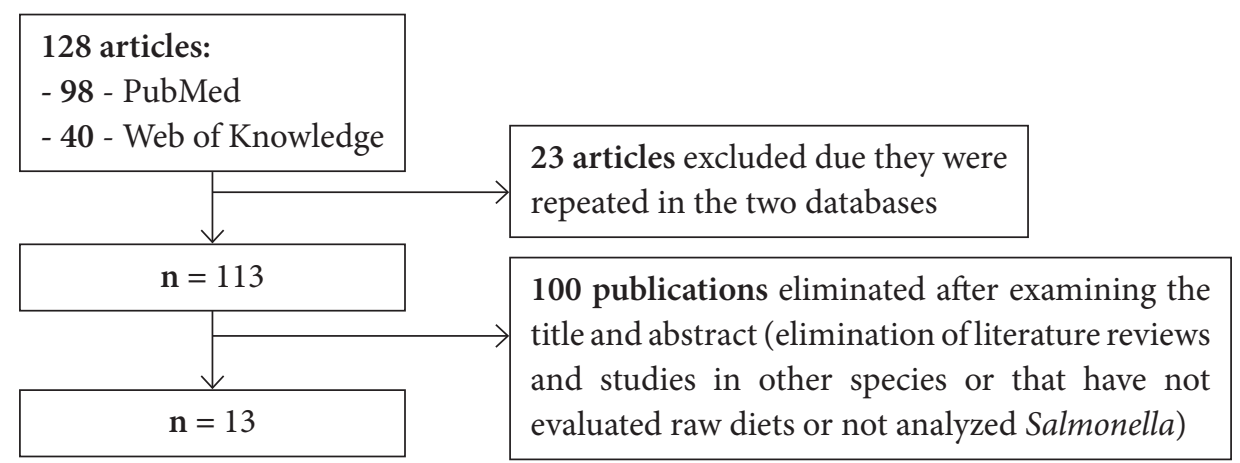

Figure 1 - Flowchart of search process

Tables 2 and 3 show the data related to the experimental design and results of selected articles. The data presented in Tables 2 and 3 refer only to raw meat diets and faeces of animals fed raw meat diets; therefore, data regarding diets without raw meat or animals that were not fed these diets were not described in the present work.

In 11 studies microbiological analysis had been conducted for Salmonella in the raw meat diet, and four of them had also analysed the presence of Salmonella in dog faeces. Two studies assessed only microbiological contamination in faeces. Out of the eleven studies that performed dietary analysis, only one did not find Salmonella, and only one did not specify the serotype of Salmonella found in food. The serotype $S$. Typhimurium was found in four studies; the serotypes S. Agona, S. Anatum, S. Hadar, S. Kentucky, $S$. Newport, and $S$. Schwarzengrund were found in three studies; the serotypes $S$. Dublin, $S$. Heidelberg, $S$. Infantis, I: 4,12:-:-, I: ROUGH:O:r:1,2, S. Mbandaka, S. Montevideo, $S$. Muenster, $S$. Reading, and $S$. Thompson were observed in two studies; while the remaining 14 serotypes were observed in only one of the nine studies.

Eleven studies that performed dietary analysis in a total of 679 diets containing raw meat were analysed, among which 141 (20.76\%) samples were contaminated with Salmonella. From the nine studies that reported the presence of Salmonella and identified serotypes, 480 diets were analysed, of which 126 (26.25\%) were infected by one or more serotypes of Salmonella. The serotypes most commonly found were $S$. Typhimurium (24.60\%), S. Heidelberg (19.05\%); S. Hadar (9.52\%), S. Agona (6.35\%), S. Newport (6.35\%), S. Schwarzengrund (4.76\%), S. Infantis (4.76\%), S. Muenster (4.76\%), S. Anatum (3.17\%), S. Reading (3.17\%), S. Thompson (2.38\%); S. Kentucky (2.38\%), I:4,12:-:- (2.38\%); S. Mbandaka (1.59\%), I:ROUGH-O:r:1,2 (1.59\%), S. Dublin (1.59\%), $S$. Montevideo (1.59\%). The remaining serotypes (others) found in studies corresponded to a prevalence of $0.01 \%$ (Figure 2).

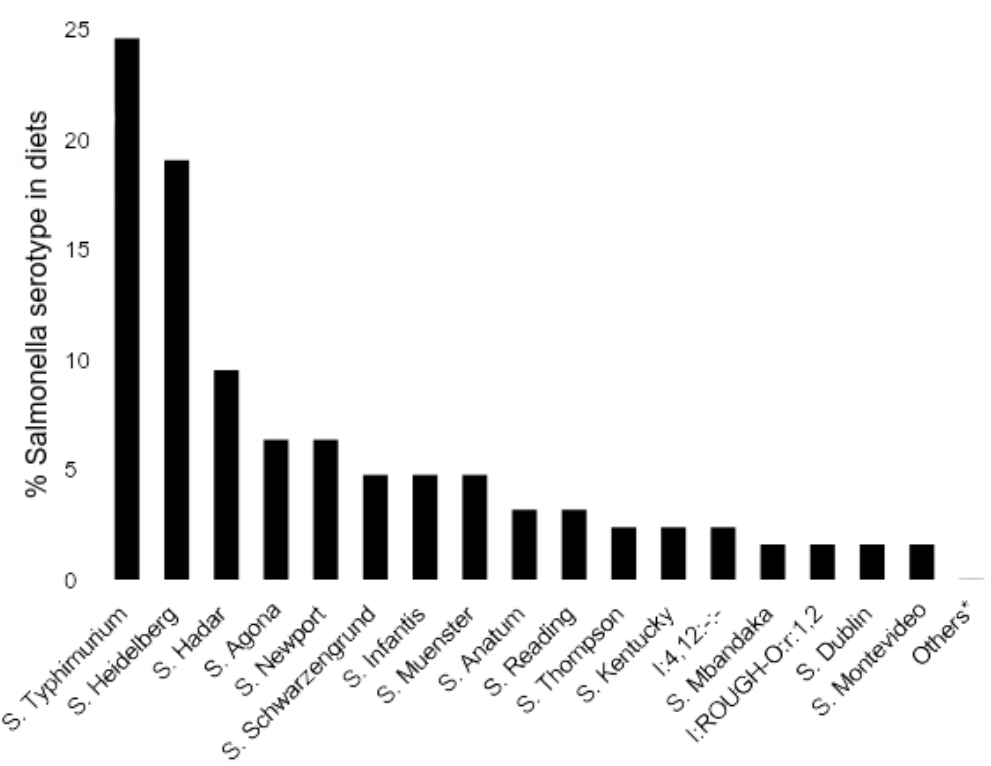

Figure 2 - Percentage of Salmonella serotypes in diets for dogs containing raw meat; each diet may have been positive for more than one serotype ( ${ }^{\star}$ Others - corresponds to 14 different serotypes) 


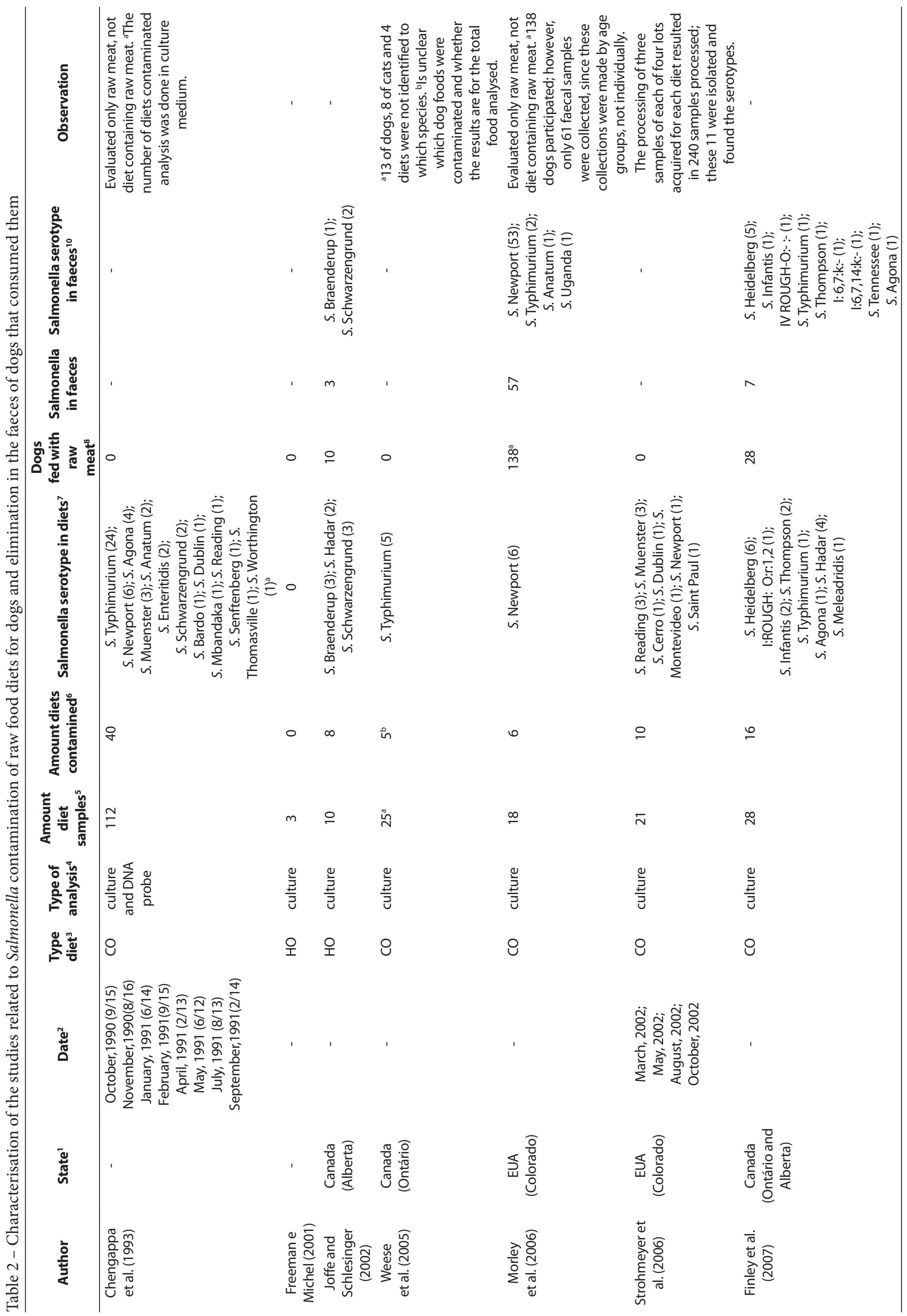




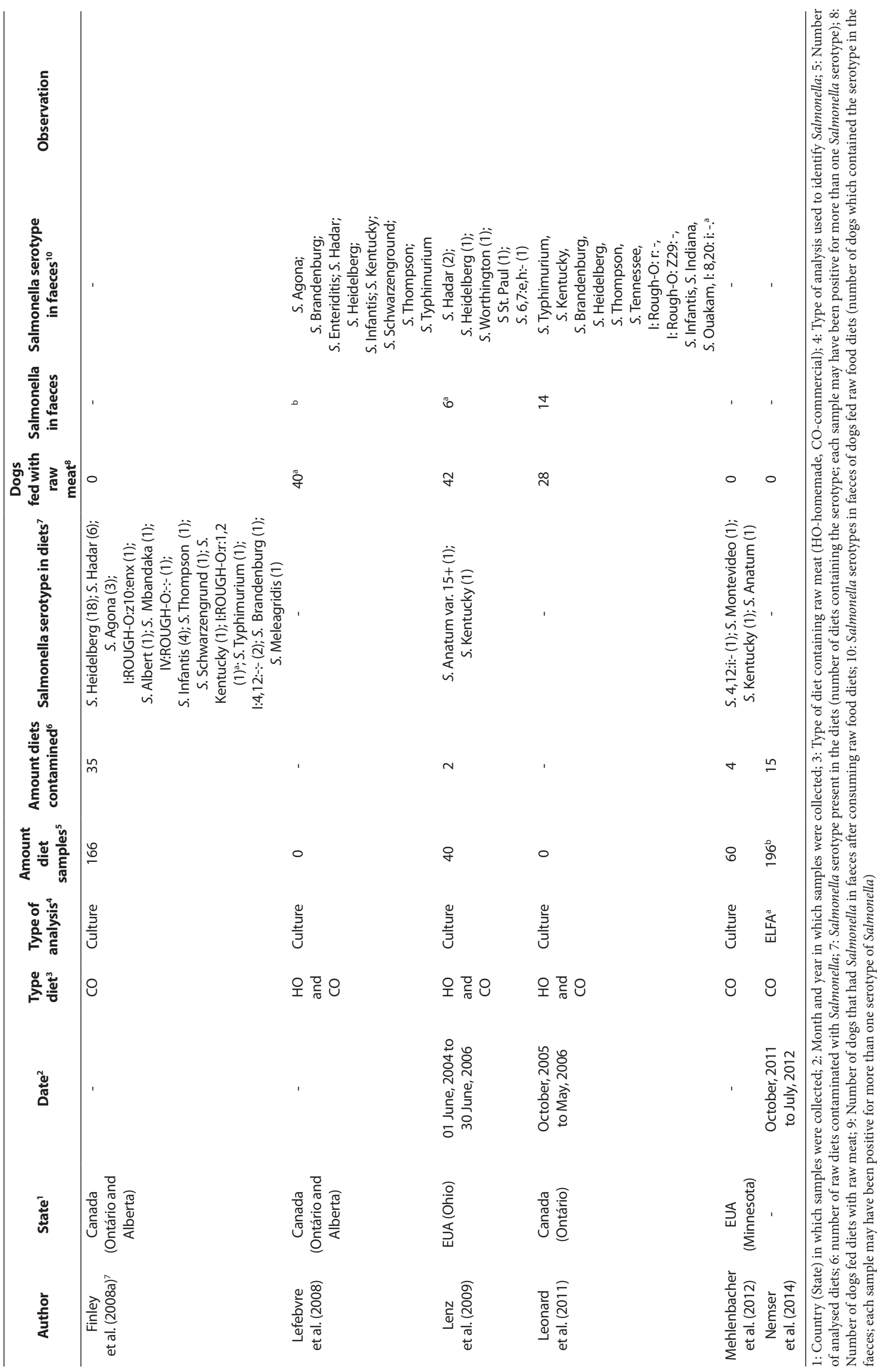

Braz. J. Vet. Res. Anim. Sci., São Paulo, v. 54, n. 4, p. 306-318, 2017 
Four studies related the type of raw meat to the serotype of Salmonella in food, and four studies related the serotype of Salmonella found in the food and in the faeces. All these studies observed a different elimination of serotypes from those found in food. Even so, in two studies Salmonella was not found in food, but it was found in the faeces of dogs, and in two studies, there was an occurrence of contamination in food, but not in faeces (Table 3).

Table 3 - Data relating to studies that related serotype of Salmonella present in the feed to the type of raw meat and/or serotype of Salmonella excreted in the faeces

\begin{tabular}{|c|c|c|c|}
\hline Author & Meat type & Serotype of Salmonella in the diet & Serotype of Salmonella in the feeces \\
\hline \multirow{9}{*}{$\begin{array}{l}\text { Joffe and } \\
\text { Schlesinger } \\
\text { (2002) }\end{array}$} & \multirow[t]{9}{*}{ Chicken } & S. Braenderup & Negative \\
\hline & & S. Braenderup & Negative \\
\hline & & S. Hadar & Negative \\
\hline & & S. Schwarzengrund & S. Schwarzengrund \\
\hline & & S. Schwarzengrund & S. Braenderup \\
\hline & & S. Hadar & Negative \\
\hline & & S. Schwarzengrund & Negative \\
\hline & & S. Braenderup & Negative \\
\hline & & Negative & S. Schwarzengrund \\
\hline $\begin{array}{l}\text { Morley } \\
\text { et al. (2006) }\end{array}$ & Beef & S. Newport & $\begin{array}{l}\text { S. Newport; S. Typhimurium; } \\
\text { S. anatum; S. uganda }\end{array}$ \\
\hline \multirow{16}{*}{$\begin{array}{l}\text { Finley } \\
\text { et al. (2007) }\end{array}$} & \multirow[t]{16}{*}{-} & S. Heidelberg & S. Heidelberg \\
\hline & & S. Heidelberg; I:ROUGH: O:r:1,2 & S. Heidelberg \\
\hline & & S. Heidelberg & S. Heidelberg \\
\hline & & S. Infantis; S. Heidelberg & S. Infantis; IV ROUGH-O :- :-; S. Heidelberg \\
\hline & & S. Thompson & S. Typhimurium \\
\hline & & S. Typhimurium & S. Thompson; I: 6,7:k:-; l:6,7,14:k:- \\
\hline & & S. Agona & S. Tennessee; S. Agona; S. Heidelberg \\
\hline & & S. Infantis & Negative \\
\hline & & S. Heidelberg & Negative \\
\hline & & S. Heidelberg & Negative \\
\hline & & S. Hadar & Negative \\
\hline & & S. Hadar & Negative \\
\hline & & S. Hadar & Negative \\
\hline & & S. Hadar & Negative \\
\hline & & S. Thompson & Negative \\
\hline & & S. Meleadridis & Negative \\
\hline \multirow[t]{6}{*}{$\begin{array}{l}\text { Finley } \\
\text { et al. (2008b) }\end{array}$} & Chicken & $\begin{array}{l}\text { S. Heidelberg; S. Hadar; S. Agona; I:ROUGH-O:z10:enx; } \\
\text { S. Albert; S. Mbandaka; IV:ROUGH-O:-:-; S. Infantis; } \\
\text { S. Thompson; S. Schwarzengrund; S. Kentucky; } \\
\text { I:ROUGH-O:r:1,2 }\end{array}$ & - \\
\hline & Turkey & S. Heidelberg; S. Typhimurium; I:4,12:-:- & \\
\hline & Buffalo & S. Agona; S. I:4,12:-:- & \\
\hline & Chicken and others* & $\begin{array}{l}\text { S. Heidelberg; S. Infantis; } \\
\text { S. Brandenburg; I:ROUGH-O:r:1,2 }\end{array}$ & \\
\hline & Others $^{\dagger}$ & S. Heidelberg; S. Meleagridis & \\
\hline & Not recorded & S. Infantis; S. Heidelberg & \\
\hline $\begin{array}{l}\text { Lenz } \\
\text { et al. (2009) }\end{array}$ & - & $\begin{array}{l}\text { S. Anatum var. 15+ } \\
\text { Negative } \\
\text { Negative } \\
\text { Negative } \\
\text { S. Kentucky } \\
\text { Negative }\end{array}$ & $\begin{array}{l}\text { S. Hadar } \\
\text { S. Heidelberg } \\
\text { S. Worthington } \\
\text { S. Hadar } \\
\text { S. Saintpaul } \\
\text { 6,7:e,h:- }\end{array}$ \\
\hline $\begin{array}{l}\text { Mehlenbacher } \\
\text { et al. (2012) }\end{array}$ & $\begin{array}{l}\text { Duck } \\
\text { Chicken } \\
\text { Bison } \\
\text { Tripe }\end{array}$ & $\begin{array}{l}\text { 4, 12:i:- } \\
\text { S. Montevideo } \\
\text { S. Kentucky } \\
\text { S. Anatum }\end{array}$ & - \\
\hline
\end{tabular}

* Beef (2 diets); turkey (2 diets) and salmon (1 diet)† Lam (26 diets), beef (24 diets); rabbit (6 diets), ham (3 diets), ground tripe (2 diets), ostrich (2 diets), duck (1 diet), llama (1 diet), elk (1 diet), goat (1 diet), ostrich and emu (2 diets), bison (1 diet), and goat and carp fish (1 diet) 
In the studies conducted in Canada, the serotype that was prevalent in contaminated food (37.5\%) and faeces (50\%) was $S$. Heidelberg. In the studies performed in the USA, the prevalent serotypes in contaminated food were S. Muenster (13.64\%) and S. Reading (13.64\%), and that in contaminated faeces was $S$. Newport (84.13\%).

Five studies evaluated other pathogens besides Salmonella in the diet. Determination of $E$. coli in food was made in five studies, in which were evaluated 287 diets and 37 (12.89\%) were positive for this pathogen. Campylobacter spp was examined in three studies (86 diets), but was not found in any of the samples. Listeria monocytogenes was analysed in only one study, in which out of the total 196 diets 32 (16.32\%) had the pathogen. Faecal coliforms, spore-forming bacteria, Clostridium perfringens (C. perfringens), Clostridium difficile (C. difficile), and Staphylococcus aureus (S. aureus) were analysed in only one study; $100 \%$ of the samples $(n=25)$ were contaminated by faecal coliform and spore-forming bacteria, $20 \%$ of the diets presented C. perfringens, $4 \%$ exhibited C. difficile, and $4 \%$ presented S. aureus. In faecal samples from dogs fed with diets containing raw meat, only two studies examined other pathogens. In one study faecal contamination by E. coli and C. difficile was found and in the other there was only $C$. jejuni.

Six studies evaluated the presence of Salmonella in faeces. The serotypes $S$. Typhimurium and $S$. Heidelberg were found in four studies; the serotypes $S$. Thompson and $S$. Infantis, in three studies; the serotypes $S$. Agona, $S$. Hadar, I:6,7, S. Kentucky, S. Schwarzengrund, $S$. Tennessee, and $S$. Brandenburg, in two studies, while the remaining 14 serotypes were observed in only one out of six studies.

Out of the six studies, two did not report the number of dogs that eliminated the serotype of Salmonella in their faeces. Thus, of the 141 faecal samples analysed in four studies, $73(51.77 \%)$ were contaminated. The serotypes most commonly found were $S$. Newport $(72.60 \%)$, S. Heidelberg (8.22\%), S. Typhimurium (4.11\%), S. Schwarzengrund (2.74\%), S. Hadar (2.74\%), and S. I: 6,7 (2.74\%). The remaining 14 serotypes found (others) in studies corresponded to a prevalence of $6.85 \%$ (Figure 3 ).

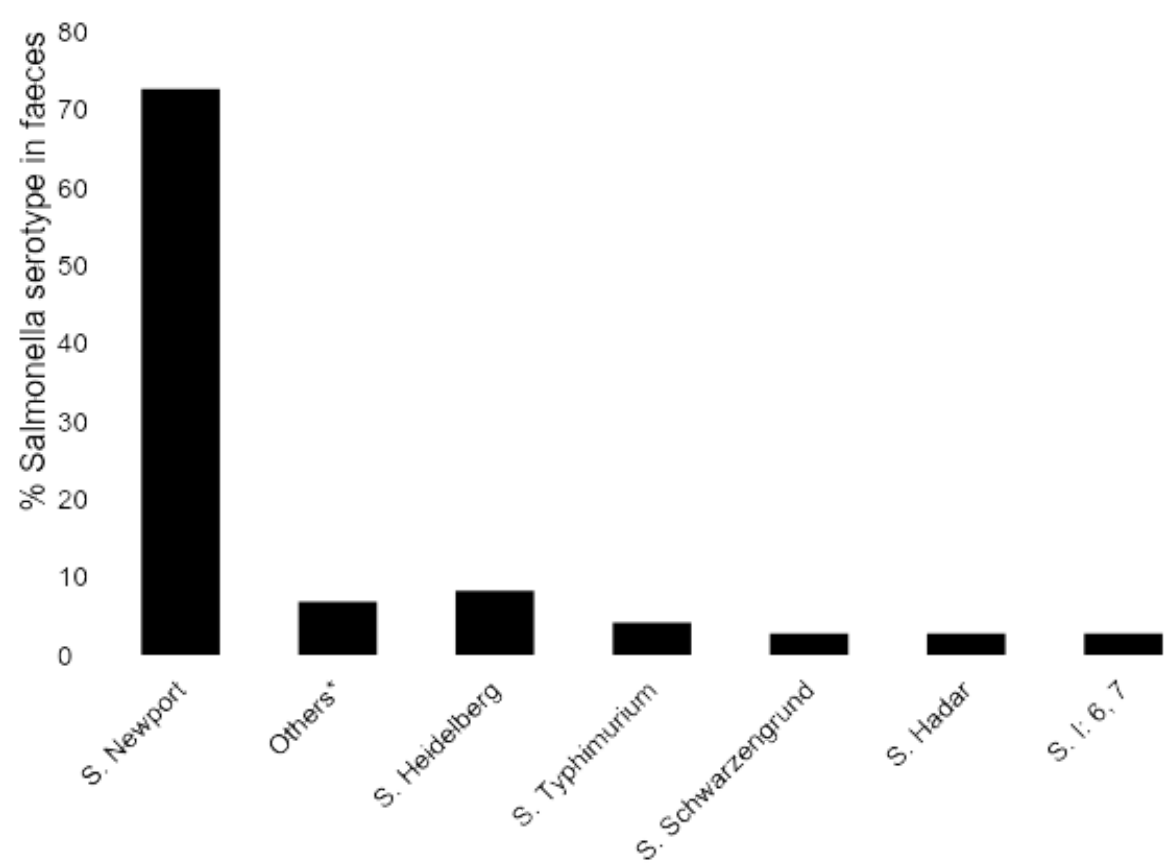

Figure 3 - Percentage of Salmonella serotypes in faeces of dogs fed diets containing raw meat; each diet may have been positive for more than one serotype ( ${ }^{\star}$ Others - corresponds to 14 different serotypes)

\section{Discussion and Conclusion}

This systematic review was performed to assess the prevalence of Salmonella in raw meat diets for dogs and the potential risk for humans. Although it was a judicious search performed by the authors, the limitations of this study are related to scientific articles that may not have been recovered in databases due to variations in the titles, indices, and keywords. Although there are studies reporting the contamination of pig-ear pet treats (FINLEY et al., 2008b), the persistence of Salmonella, and the effects of different regimes of cleaning and disinfection of bowls containing the microorganism (WEESE; ROUSSEAU, 
2006) and zoonotic disease-related husbandry, as well as infection-preventive practices in pet-owning households (STULL et al., 2013), only articles where microbiological analysis was performed for the identification of Salmonella in raw food diets and/or faeces of dogs consuming this type of diet were selected for this study. It is worth mentioning that the criteria for assessing the methodological quality were defined based on previous research and the experience of the authors, although the standardisation of the methodology of the studies found for the preparation of the systematic review was not homogeneous, as can be seen in other areas of research.

The contact with animals and their environment can be a powerful mode of transmission of enteric pathogens. Hale et al. (2012) suggests that $14 \%$ of all human diseases caused by seven groups of common enteric pathogens (Campylobacter spp.; Cryptosporidium spp.; Shiga toxinproducing E. Coli 0157; Non-O157 Shiga toxin-producing E. coli, Listeriamonocytogenes, non-typhoidal Salmonella spp., and Yersinia enterocolítica) are caused by contact with animals.

An example was the human infection by Salmonella linked to pet food. In 2012 in Canada and the United States 2 and 47 people respectively were infected by strains of Salmonella enterica serotype Infantis after exposure to dry dog food (MULTISTATE..., 2012). Li et al. (2012) analysing the prevalence of Salmonella in pet food (complete animal feeds, feed ingredients, pet foods, pet treats, and supplements) in 2002-2009 observed that, out of 2058 samples collected, 257 (12.5\%) were contaminated with Salmonella, being the highest prevalence found in animal ingredients, not derived from plants ingredients.

Thus, humans infected with Salmonella by contact with pet food have been a concern. In addition, with the high popular trend of feeding dogs raw meat diets, it has been observed that their owners are exposed to a higher risk of being infected by salmonella either by contact with the food or directly from the animal (FINLEY et al., 2007).

Thereby, based on the results obtained from the work of this systematic review, it was observed that commercial and homemade diets containing raw meat for dogs may be contaminated with zoonotic microorganisms, especially Salmonella, therefore presenting risk of human contamination. The faecal shedding of Salmonella for dogs without clinical signs of disease creates the possibility of zoonotic transmission of disease through direct contact or through environmental contamination.
It is also believed that some Salmonella serotypes are more likely to be eliminated than others, which was observed in two studies of this systematic review (JOFFE; SCHLESINGER, 2002; FINLEY et al., 2007), as the food was found to be contaminated, but no pathogen was identified in the faeces. In the study by Joffe and Schlesinger (2002) it was observed that $S$. Braenderup, $S$. Hadar, and $S$. Schwarzengrund were found in diets, but were not eliminated by some animals. In the study performed by Finley et al. (2007) most of the dogs which were fed raw food diets contaminated with $S$. Heidelberg and $S$. Infantis had the same pathogens recovered from their faecal samples, whereas dogs fed raw food diets contaminated with $S$. Hadar and S. Meleagridis and some fed $S$. Infantis, $S$. Thompson, and $S$. Heidelberg did not excrete the pathogens during the experimental period. In the discussion Finley et al. (2007) stated that there might be a difference in the probability of elimination of the serovar, which may be related to the size of the inoculum, survival in the matrix of the frozen raw food diet, or the ability to colonise the intestine of the dog.

There have also been some studies where Salmonella serotypes found in the faeces differed from isolates in the food consumed by the animals. This may have been due to the acquisition of the pathogen in other ways, such as from the environment or other contaminated media, since Salmonella can survive for long periods in the environment, especially when it is hot and humid (CFSPH, 2005), via the ingestion of water, or by even by prior exposure of the animal to other serotypes. The latter suggestion was not considered in many studies, which did not undergo previous collections proving the absence, on consecutive days, of Salmonella in the faeces of dogs.

Many factors are involved in the infection occurrence from diets, and can highlight the quality of ingredients used and common types of pathogens in animals for slaughter, as well as hygiene and thermal control in the processing, transportation, and storage of food. It is worth mentioning that there are some types of meat that tend to be more easily contaminated by a particular pathogen, such as Salmonella, which is often associated with chicken and its derivatives (BRYAN; DOYLE, 1995). This fact was clearly seen in one of the studies used in this review (FINLEY et al., 2008a), in which $67 \%$ of the diets positive for Salmonella contained raw chicken meat. Previously, Strohmeyer et al. (2006) had isolated the agent in only $2.1 \%$ of samples of raw chicken meat in dog food. For human consumption, a study 
observed $20 \%$ - 35\% contamination of poultry carcasses (ALTEKRUSE et al., 1999), whereas in another study that conducted market analysis for three years the presence of Salmonella was observed in $44.6 \%$ of samples of chicken and in $49.9 \%$ of samples of turkey. However, the high prevalence of Salmonella in human food implies greater care with the dog foods, because the diet of humans generally passes through thermal processing before consumption (WEESE; ROUSSEAU; ARROYO, 2005).

In addition, several kinds of meat are potential means of transmission of Salmonella due to the possibility of contamination during slaughter and survival of the pathogen in fresh meat and meat that is not properly heated (HENDRIKSEN, 2010). Although many studies have only reported the importance of raw meat used in the preparation of the diet, it is important to highlight that raw diets have other ingredients, such as vegetables and eggs and derivatives, which may also contribute to the increased risk of contamination by Salmonella; these are, however, often unreported on product labels or in studies.

The study conducted by Mehlenbacher et al. (2012), in which were purchased diets classified commercially as raw diets, even though some had undergone processing such as freeze drying, dehydration or HPP (High Pressure Processing), raised the question of the importance of defining raw diets and processing in reducing the risk of Salmonella contamination. In the results obtained by the authors the four diets that were positive for Salmonella had not undergone any processing, whereas the pathogen was not recovered in processed samples, perhaps providing further evidence for the use of processing methods such as freeze drying or HPP to prevent bacterial contamination.

It is difficult to compare the prevalence estimates obtained from different studies, since, although they may reveal the true differences in the distribution of Salmonella among geographic regions, differences may also be due to the techniques used to determine the prevalence of Salmonella. Nevertheless, as reported in one study (CIPARS, 2004) described by Finley et al. (2007), in Canada S. Heidelberg was the most common cause of human salmonellosis, being responsible for $26 \%$ of all isolates of Salmonella obtained from human cases in 2003. The serovar $S$. Typhimurium was the second most common (25\%), followed by S. enteritidis (15\%).

In the U.S.A. the most common serotypes isolated from humans in 2002 were, in descending order, S. Typhimurium, $S$. enteritidis, $S$. Newport, and $S$. Heidelberg, among others, and in clinically ill animals were, in descending order, $S$. Typhimurium, S. Newport, S. Agona, and S. Heidelberg, among others (CFSPH, 2005). Based on the combined results of serotypes found in most samples of raw food diets for dogs in this systematic review, it was found that $S$. Typhimurium (24.60\%) and S. Heidelberg (19.05\%) were the most commonly found in contaminated samples. In faeces of dogs, $S$. Heidelberg $(8.22 \%)$ and $S$. Typhimurium (4.11\%) were the second and third most commonly eliminated serovars, respectively, whereas $S$. Newport (72.60\%) was further eliminated.

$\mathrm{Li}$ et al. (2012) identified in pet food 45 serotypes, being $S$. Senftenberg and $S$. Montevideo the most common (8.9\%) between the identified. However, these results were not consistent with the serotypes most commonly causing human infection, so justified by the increased human exposure to a variety of sources of contamination.

Cases of septicaemia by Salmonella in two cats being fed raw food diets were reported, where $S$. Newport from the meat used in their meals was found to be the cause of death in both cats. These scenarios highlight the fact that diets containing raw meat contaminated with Salmonella that are consumed by dogs can contribute to the risk of human salmonellosis, as well as in community exposure to serotypes not previously prevalent, which may eventually increase the frequency of recovery of these serotypes in humans.

The techniques used to identify the presence of Salmonella in food samples and/or faeces may also influence the results found in prevalence studies. In the study performed by Chengappa et al. (1993), which used DNA probe methodology to identify the presence of Salmonella in raw meat used for feeding dogs, it was found that $66.03 \%$ of the samples contained the pathogen, whereas only $44.64 \%$ of the samples were identified as contaminated using conventional methodology including cell culture. However, according to the authors, although the DNA probe method is more sensitive than the conventional culture method, the results of the culture method were more useful because this method provided the recognition of serotypes. Conventional methods currently used by most diagnostic laboratories for the identification and isolation of Salmonella in food are time-consuming, whereas the probe test is faster, more sensitive, and easier to perform, despite more costly.

While any person is likely to become infected with a zoonotic pathogen, those with compromised immune systems (such as elderly - $\geq 65$ years - and pregnant 
women) or with incomplete development (children $<5$ years) are at increased risk (STULL et al., 2013) and should therefore make use of hygienic practices when handling animals, their food, feed hoppers, and faeces, once the hand hygiene plays an important role in reducing the risk of zoonotic infections.

In conclusion, the use of commercial and homemade diets containing raw meat for dogs creates a potential risk for the transmission of Salmonella in humans, especially for high-risk individuals, such as children, the elderly, and the immunocompromised, either through handling food or from contact with the faeces of animals fed contaminated diets.

\section{Acknowledgements}

Capes, $\mathrm{CNPq}$ and Uniarp for supporting the study.

\section{References}

ASSOCIAÇÃO BRASILEIRA DAS INDÚSTRIAS EXPORTADORAS DE CARNES (ABIEC). Ano de 2013 começa com denúncia e termina positivo para a cadeia da carne. Clipping ABIEC, v. 1, n. 526, p. 4-5, 2014. Available from: <https://goo.gl/XWNswF>. Viewed: 13 Dec. 2017.

ALTEKRUSE, S. F.; STERN, N. J.; FIELDS, P. I.; SWERDLOW, D. L. Campylobacter jejuni: an emerging foodborne pathogen. Emerging Infectious Diseases, v. 5, n. 1, p. 28-35, 1999. doi: 10.3201/eid0501.990104.

BRYAN, F. L.; DOYLE, M. P. Health risks and consequences of Salmonella and Campylobacter jejuni in raw poultry. Journal of Food Protection, v. 58, n. 3, p. 326-344, 1995. doi: 10.4315/0362-028X-58.3.326.

CANADIAN INTEGRATED PROGRAM FOR ANTIMICROBIAL RESISTANCE SURVEILLANCE (CIPARS). Government of Canada, Toronto, 2007. Available at: <https://goo.gl/QgZUA5>. Viewed: 13 Dec. 2017.

THE CENTER FOR FOOD SECURITY AND PUBLIC HEALTH (CFSPH). Salmonellosis. Ames: CFSPH, 2005. Available at: <https://goo.gl/TnZmKY>. Viewed: 13 Dec. 2017.

CHENGAPPA, M. M.; STAATS, J.; OBERST, R. D.; GABBERT, N. H.; MCVEY, S. Prevalence of Salmonella in raw meat used in diets of racing greyhounds. Journal of Veterinary Diagnostic Investigation, v. 5, n. 3, p. 372377, 1993. doi: 10.1177/104063879300500312.

FINLEY, R.; REID-SMITH, R.; RIBBLE, C.; POPA, M.; VANDERMEER, M.; ARAMINI, J. The occurrence and anti-microbial susceptibility of Salmonellae isolated from commercially available pig ear pet treats. Zoonoses and Public Health, v. 55, n. 8-10, p. 455-461, 2008a. doi: 10.1111/j.1863-2378.2008.01144.x.

FINLEY, R.; REID-SMITH, R.; RIBBLE, C.; POPA, M.; VANDERMEER, M.; ARAMINI, J. The occurrence and antimicrobial susceptibility of Salmonellae isolated from commercially available canine raw food diets in three Canadian cities. Zoonoses and Public Health, v. 55 , n. $8-10$, p. $462-469,2008$ b. doi: 10.1111/j.18632378.2008.01147.x.

FINLEY, R.; RIBBLE, C.; ARAMINI, J.; VANDERMEER, M.; POPA, M.; LITMAN, M.; REID-SMITH, R. The risk of salmonellae shedding by dogs fed Salmonellacontaminated commercial raw food diets. The Canadian Veterinary Journal, v. 48, n. 1, p. 69-75, 2007.

FREEMAN, L. M.; CHANDLER, M. L.; HAMPER, B. A.; WEETH, L. P. Current knowledge about the risks and benefits of raw meat-based diets for dogs and cats. Journal of the American Veterinary Medical Association, v. 243, n. 11, p. 1549-1558, 2013. doi: 10.2460/javma.243.11.1549.

FREEMAN, L. M.; MICHEL, K. E. Evaluation of raw food diets for dogs. Journal of the American Veterinary Medical Association, v. 218, n. 5, p. 705-709, 2001.

HALE, C. R.; SCALLAN, E.; CRONQUIST, A. B.; DUNN, J.; SMITH, K.; ROBINSON, T.; LATHROP, S.; TOBIND'ANGELO, M.; CLOGHER, P. Estimates of enteric illness attributable to contact with animals and their environments in the United States. Clinical Infectious 
Diseases, v. 54, p. S472-S479, 2012. Supplement 5. doi: $10.1093 / \mathrm{cid} / \mathrm{cis} 051$.

HENDRIKSEN, R. Global epidemiology of nontyphoidal Salmonella infections in humans. 2010. 182 f. Tese (Doutorado) - Technical University of Denmark, Lyngby, 2010.

JOFFE, D. J.; SCHLESINGER, D. P. Preliminary assessment of the risk of Salmonella infection in dogs fed raw chicken diets. Canadian Veterinary Journal, v. 43, n. 6, p. 441-442, 2002.

LAMBERTINI, E.; BUCHANAN, R. L.; NARROD, C.; FORD, R. M.; BAKER, R. C.; PRADHAN, A. K. Quantitative assessment of human and pet exposure to Salmonella associated with dry pet foods. International Journal of Food Microbiology, v. 216, p. 79-90, 2016. doi: 10.1016/j.ijfoodmicro.2015.09.005.

LEFEBVRE, S. L.; REID-SMITH, R.; BOERLIN, P.; WEESE, J. S. Evaluation of the risks of shedding Salmonellae and other potential pathogens by therapy dogs fed raw diets in Ontario and Alberta. Zoonoses and Public Health, v. 55, n. 8-10, p. 470-480, 2008. doi: 10.1111/j.1863-2378.2008.01145.x.

LENZ, J.; JOFFE, D.; KAUFFMAN, M.; ZHANG, Y.; LEJEUNE, J. Perceptions, practices, and consequences associated with foodborne pathogens and the feeding of raw meat to dogs. Canadian Veterinary Journal, v. 50, n. 6, p. 637-643, 2009.

LEONARD, E. K.; PEARL, D. L.; FINLEY, R. L.; JANECKO, N.; PEREGRINE, A. S.; REID-SMITH, R. J.; WEESE, J. S. Evaluation of pet-related management factors and the risk of Salmonella spp. carriage in pet dogs from volunteer households in Ontario (20052006). Zoonoses and Public Health, v. 58, n. 2, p. 140149, 2011. doi: 10.1111/j.1863-2378.2009.01320.x.

LI, X.; BETHUNE, L. A.; JIA, Y.; LOVELL, R. A.; PROESCHOLDT, T. A.; BENZ, S. A.; SCHELL, T. C.; KAPLAN, G.; MCCHESNEY, D. G. Surveillance of Salmonella prevalence in animal feeds and characterization of the Salmonella isolates by serotyping and antimicrobial susceptibility. Foodborne Pathogens and Disease, v. 9, n. 8, p. 692-698, 2012. doi: 10.1089/ fpd.2011.1083.

MEHLENBACHER, S.; CHURCHILL, J.; OLSEN, K. E.; BENDER, J. B. Availability, brands, labelling and Salmonella contamination of raw pet food in the Minneapolis/St. Paul area. Zoonoses and Public Health, v. 59, n. 7, p. 513-520, 2012. doi: 10.1111/j.1863-2378.2012.01491.x.

MORLEY, P. S.; STROHMEYER, R. A.; TANKSON, J. D.; HYATT, D. R.; DARGATZ, D. A.; FEDORKA-CRAY, P. J. Evaluation of the association between feeding raw meat and Salmonella enterica infections at a Greyhound breeding facility. Journal of the American Veterinary Medical Association, v. 228, n. 10, p. 1524-1532, 2006. doi: 10.2460/javma.228.10.1524.

MULTISTATE outbreak of human Salmonella infantis infections linked to dry dog food (final update). Centers for Disease Control and Prevention, Atlanta, 2012. Available at: <https://goo.gl/WwPqwn>. Viewed: 13 Dec. 2017.

NEMSER, S. M.; DORAN, T.; GRABENSTEIN, M.; MCCONNEL, T.; MCGRATH, T.; PAMBOUKIAN, R.; SMITH, A. C.; ACHEN, M.; DANZEISEN, G.; KIM, S.; LIU, Y.; ROBESON, S.; ROSARIO, G.; MCWILLIAMS WILSON, K.; REIMSCHUESSEL, R. Investigation of Listeria, Salmonella, and toxigenic Escherichia coli in various pet foods. Foodborne Pathogens and Disease, v. 11, n. 9, p. 706-709, 2014. doi: 10.1089/fpd.2014.1748.

PEREIRA, U. P.; OLIVEIRA, D. G. S.; MESQUITA, L. R.; COSTA, G. M.; PEREIRA, L. J. Efficacy of Staphylococcus aureus vaccines for bovine mastitis: a systematic review. Veterinary Microbiology, v. 148, n. 2-4, p. 117-124, 2011. doi: 10.1016/j.vetmic.2010.10.003.

STROHMEYER, R. A.; MORLEY, P. S.; HYATT, D. R.; DARGATZ, D. A.; SCORZA, A. V.; LAPPIN, M. R. Evaluation of bacterial and protozoal contamination of commercially available raw meat diets for dogs. Journal of the American Veterinary Medical Association, v. 228, n. 4, p. 537-542, 2006. doi: 10.2460/javma.228.4.537.

STULL, J. W.; PEREGRINE, A. S.; SARGEANT, J. M.; WEESE, J. S. Pet husbandry and infection control practices related to zoonotic disease risks in Ontario, Canada. 
BMC Public Health, v. 187, n. 10, p. 736-743, 2013. doi: 10.1186/1471-2458-13-520.

WEESE, J. S.; ROUSSEAU, J. Survival of Salmonella Copenhagen in food bowls following contamination with experimentally inoculated raw meat: effects of time, cleaning, and disinfection. Canadian Veterinary Journal, v. 47, n. 9, p. 887-889, 2006.

WEESE, J. S.; ROUSSEAU, J.; ARROYO, L. Bacteriological evaluation of commercial canine and feline raw diets. Canadian Veterinary Journal, v. 46, n. 6, p. 513-516, 2005. 